\title{
Notatka ze spotkania informacyjnego dot. Programów Interreg Europa, Interreg Europa Środkowa, Interreg Morza Bałtyckiego na lata 2021-2027
}

Dnia 15 marca 2021 r. odbyło się spotkanie informacyjne dotyczące Programów Interreg Europa, Interreg Europa Środkowa, Interreg Morza Bałtyckiego na lata 2021-2027 zorganizowane przez Ministerstwo Funduszy i Polityki Regionalnej. Podczas spotkania omówiono zasady tych programów, zakres tematyczny, charakterystykę projektów, a także planowane terminy pierwszych naborów wniosków. Charakterystykę programów uzupełniają przykłady projektów zrealizowanych z udziałem polskich instytucji w okresie 2014-2020. Dzięki współpracy z urzędami marszałkowskimi zaprezentowane zostały także doświadczenia poszczególnych województw w zakresie współpracy transnarodowej i międzyregionalnej.

\section{Programy Interreg Region Morza Bałtyckiego i Interreg Europa Środkowa Monika Strojecka-Gevorgyan, Ministerstwo Funduszy i Polityki Regionalnej, Departament Współpracy Terytorialnej (MFiPR DWT)}

Projekty transnarodowe dotyczą wyzwań, z którymi pojedyncze państwa nie są w stanie się zmierzyć samodzielnie i które wymagają wspólnych działań partnerów z kilku państw obszaru objętego programem. Partnerzy z kilku państw muszą wspólnie realizować główne działania w ramach projektu. Projekt tworzy przynajmniej trzech partnerów finansujacych z trzech krajów, z których co najmniej dwóch ma siedzibę na obszarze programu.

Przykłady działań w projektach transnarodowych:

- wspólne opracowywanie i wdrażanie strategii lub planów działania,

- opracowywanie i ustanawianie modeli współpracy, platform transferu wiedzy i wspólnego zarządzania,

- $\quad$ tworzenie map zasobów w wybranym obszarze tematycznym i opracowywanie propozycji ich efektywnego wykorzystywania,

- inwestycje pilotażowe, studia wykonalności i planowanie przedinwestycyjne,

- testowanie nowych rozwiązań (np. technologii) i promowanie ich stosowania.

Projekty o charakterze wyłącznie badawczym, niewskazujące sposobu wykorzystania rezultatów w praktyce, nie moga liczyć na dofinansowanie.

Interreg Europa Środkowa 2014-2020

- Zasięg geograficzny: Polska, Czechy, Słowacja, Austria, Węgry, Słowenia, Chorwacja, północne Włochy i część Niemiec 
- Budżet: 246 mln euro - EFRR

- Instytucja Zarządzająca - Miasto Wiedeń

Priorytety Interreg Region Europa Środkowa 2014-2020

1. Innowacje na rzecz zwiększenia konkurencyjności

2. Strategie niskoemisyjne

3. Zasoby naturalne i kulturowe na rzecz trwałego wzrostu gospodarczego

4. Poprawa powiązań transportowych

Zatwierdzono 138 projektów z udziałem 188 PL partnerów (w tym 14 liderów)

\section{Interreg Region Morza Bałtyckiego 2014-2020}

- Zasięg geograficzny: Polska, Dania, Estonia, Finlandia, Łotwa, Litwa, Szwecja, część Niemiec, Norwegia oraz część Rosji i Białoruś

- $\quad$ Budżet: 264 mln euro - EFRR

- Instytucja Zarządzająca - IB.SH

Priorytety Interreg Region Morza Bałtyckiego 2014-2020

1. Potencjał dla innowacji

2. Efektywne gospodarowanie zasobami naturalnymi

3. Zrównoważony transport

4. Zdolność instytucjonalna w zakresie współpracy makroregionalnej

Zatwierdzono 140 projektów z udziałem 207 PL partnerów (w tym 10 liderów)

\section{Projekt Interreg Europa Środkowa Forget Heritage}

Grzegorz Boroń, Urząd Miasta Bydgoszczy, Wydział zintegrowanego rozwoju i środowiska

Forget Heritage - pn. Innowacyjne, zrównoważone i replikowane modele współpracy publiczno-prywatnej w ramach ochrony porzuconych obiektów wartości historycznej poprzez wzmacnianie sektora kulturowego i kreatywnego jest kontynuacją nowoczesnego myślenia o dziedzictwie $\mathrm{z}$ dodaniem aspektu biznesowego.

Cel: Tworzenie międzynarodowego modelu zarządzania dziedzictwem kulturowym.

Działania - co udało się zrobić:

- Podręczniki pomagające zarządzać dziedzictwem

- 8 projektów pilotażowych

- Spotkania partnerów projektu, wizyty studyjne, konferencje międzynarodowe

- Lokalne spotkania sieciujące osoby z kręgów kreatywnych z miastem, instytucjami, szkolenia, warsztaty

- Aplikacja do inwentaryzacji pustostanów w mieście

- Opracowanie ogólnego modelu - strategii zarządzania dziedzictwem

Proces tworzenia pilotażu był dość długi.

Stworzone zostało Centrum Kreatywności Młodzi rzemieślnicy na Starym Mieście. Dostęp do miejsc pracy dla młodych ludzi w sektorze kreatywnym i rzemiosła. Warsztaty rzemieślnicze różnego rodzaju (od kaletnictwa po robotykę). 


\section{W ramach projektu:}

- Stworzone zostało środowisko dla młodych kreatywnych ludzi

- Wykorzystano opuszczony lokal

- Powstały nowe produkty i usługi

- Odnowiona została moda na rzemiosło

- Zastosowano współpracę publiczno-prywatna

- Wsparty został proces rewitalizacyjny

- Kontynuowane sa działania w tym obszarze

W czasie pandemii, kiedy zajęcia nie mogły się odbywać, w Pracowni zorganizowano centrum koordynacji pomocy dla medyków. Sprzęt wykorzystano do szycia maseczek i produkcji przyłbic. Wartość dodana: w pracowni odbywają się warsztaty artystyczne w języku ukraińskim, cieszą się dużą popularnością.

\section{Program Interreg Europa}

Anna Stol, Ministerstwo Funduszy i Polityki Regionalnej,

Departament Współpracy Terytorialnej (MFiPR DWT)

\section{Charakterystyka współpracy międzyregionalnej}

Program Interreg Europa 2014-2020:

- Obejmuje całe terytorium Unii Europejskiej, Norwegię i Szwajcarię.

- Wspiera współpracę regionów o różnym stopniu doświadczenia.

- Służy poprawie efektywności polityk regionalnych.

- Oferuje możliwość pogłębiania wiedzy w wybranych dziedzinach rozwoju regionalnego.

2. Co odróżnia Interreg Europa od programów transnarodowych i transgranicznych

- Ma większy zasięg geograficzny - 30 państw.

- Przyczynia się do transferu dobrych praktyk, szczególnie do programów celu Inwestycje na rzecz wzrostu i zatrudnienia (w Polsce to regionalne i krajowe programy operacyjne).

- W projektach są realizowane dwa poziomy współpracy: międzynarodowy (w ramach partnerstwa) oraz regionalny (grupy interesariuszy).

- Oferuje dodatkowe wsparcie eksperckie - Platforma learningowa programu Interreg Europa.

3. Priorytety programu Interreg Europa 2014-2020

- Badania i innowacje

- Konkurencyjność MŚP

- Gospodarka niskoemisyjna

- Ochrona środowiska oraz zarządzanie zasobami naturalnymi i kulturowymi

4. Program w liczbach:

- 258 projektów, ponad 2000 partnerów

- 94 pilotaże 
- 322 mln euro z EFRR

- Polska w programie: 101 projektów w 16 województwach; 113 partnerów (w tym 3 wiodących); 4 pilotaże; 2 wzajemne oceny; ponad 13 mln euro z EFRR

5. Platforma learningowa Interreg Europa:

- Wzajemne oceny (peer reviews)

- Policy help-desk

- Tematyczne webinaria (Przykłady tematycznych webinariów: Dziedzictwo kulturowe szansa dla zrównoważonej turystyki; Logistyka miejskiego transportu towarowego; Powtórne użycie wody oraz Europejski Zielony Ład; Cyfrowe ekosystemy innowacji).

- Tematyczne publikacje

- Baza dobrych praktyk

- Europejska społeczność praktyków

www.interregeurope.eu/policylearning

www.interregeurope.eu/discover-projects/

\section{Projekty Interreg Europa E-COOL i POWERTY}

Anna Bednarska, Stowarzyszenie Aglomeracja Opolska

1. „Podstawy przedsiębiorcze i kreatywne u młodych ludzi poprzez dynamizację kompetencji, metod nauczania i ekosystemu przedsiębiorczości" - E-COOL

Czas realizacji projektu: 01.06.2018 - 31.05.2023

Ogólnym celem projektu E-COOL jest poprawa skuteczności polityki regionalnej w promowaniu ducha przedsiębiorczości wśród młodzieży, przyczynianie się do przyszłego rozwoju gospodarczego i zwiększania konkurencyjności UE.

W projekcie uczestniczy 10 partnerów międzynarodowych oraz partnerzy regionalni.

Zrealizowane zadania:

- Udział w 3 Międzynarodowych Seminariach Wymiany Dobrymi Praktykami (Brno, Jelgava, Groningen).

- Udział w posiedzeniach Komitetu Sterującego.

- Organizacja 7 spotkań z Partnerami Regionalnymi, podczas których dokonano oceny dobrych praktyk wszystkich partnerów projektu.

- Identyfikacja dobrej praktyki do zaimplementowania na obszarze województwa opolskiego - Talento Emprendador z Hiszpanii.

- Przygotowanie Planu działania (strategicznego dokumentu) wdrożenia dobrej praktyki. 


\section{Wyzwania i oczekiwania:}

- Zmiany w podejściu do nauczania przedsiębiorczości ludzi młodych.

- Zachęcanie ludzi młodych do samorealizacji zawodowej poprzez zakładanie własnej działalności gospodarczej.

- Przyczynienie się do realnego wpływu na zmianę polityki regionalnej.

- Zachęcenie do współpracy szkół podstawowych i ponadpodstawowych do realizacji Planu działania (Action Plan).

- Zaadaptowanie elementów dobrej praktyki z Hiszpanii - Talento Emprendador poprzez sfinansowanie i wdrożenie założeń Planu działania.

2. „Odnawialne źródła energii dla grup wrażliwych" - POWERTY

Czas realizacji projektu: 01.08.2019-31.07.2023

\section{Założenia projektu:}

- projekt powstał z myśla o ulepszeniu instrumentów polityki, aby ułatwić grupom wrażliwym korzystanie z energii odnawialnej;

- zmniejszenie poziomu ubóstwa energetycznego w UE.

\section{Cele projektu:}

- Ułatwienie korzystania z energii osobom z grup wrażliwych, dotkniętych ubóstwem energetycznym, a tym samy walka z ubóstwem energetycznym.

- Identyfikacja nowych innowacyjnych technologii energii odnawialnej - skierowane do wrażliwych grup, w tym zbiorowych i miejskich systemów energetycznych.

- Stworzenie mechanizmów finansowania energii odnawialnej odpowiednich dla grup wrażliwych.

- Ulepszenia w normach prawnych dotyczących energii odnawialnej i samych grup wrażliwych.

- Wzmocnienie pozycji słabszych grup społecznych oraz innowacji społecznych służących stymulowaniu aktywnego uczestnictwa obywateli w tych grupach społecznych.

\section{Zrealizowane zadania:}

- Przygotowanie analizy SWOT do projektu w kontekście ubóstwa energetycznego na obszarze województwa opolskiego.

- Zorganizowanie kilkunastu spotkań w celu wymiany doświadczeń oraz pozyskania nowych Partnerów Regionalnych; zorganizowanie czterech spotkań z Partnerami Regionalnymi.

- Udział w seminariach międzynarodowych oraz posiedzeniach Komitetu Sterujaccego.

- Identyfikacja dobrej praktyki projektu POWERTY - domy modułowe z wykorzystaniem odnawialnych źródeł energii.

- Organizacja I Międzynarodowego Seminarium Tematycznego z przedstawieniem prezentacji dobrych praktyk.

- Stworzenie vloga tematycznego POWER i Ty.

- Udział w ogólnopolskim festiwalu ekoenergetyki. 


\section{V.Źródła informacji o programach współpracy transnarodowej i międzyregionalnej}

Monika Strojecka-Gevorgyan, Ministerstwo Funduszy i Polityki Regionalnej,

Departament Współpracy Terytorialnej (MFiPR DWT)

- www.ewt.gov.pl

- www.interreg-central.eu

- www.europasrodkowa.gov.pl

- www.interreg-baltic.eu

- www.interregeurope.eu

- Strona internetowa bazy danych KEEP https: / keep.eu /

\section{Zakres tematyczny programów i planowane typy projektów: Interreg Europa Środkowa 2021-2027 oraz Interreg Region Morza Bałtyckiego 2021-2027 \\ Monika Strojecka-Gevorgyan, Anna Stol, Ministerstwo Funduszy i Polityki Regionalnej, Departament Współpracy Terytorialnej (MFiPR DWT)}

\section{A. Interreg Europa Środkowa 2021-2027}

Główne cele i założenia programu:

- $\quad$ wspieranie miast i regionów w poszukiwaniu najlepszych rozwiązań dla mieszkańców przez współpracę ponad granicami;

- budowanie odporności regionów wobec wspólnych wyzwań, niezależnych od przebiegu granic i niemożliwych do rozwiązania bez współpracy z partnerami; wyzwania te obejmują m.in. proces transformacji gospodarczej, zmiany klimatyczne, długofalowe społeczno-ekonomiczne skutki pandemii;

- umożliwienie współdziałania instytucji publicznych, sektora prywatnego i społeczeństwa obywatelskiego i budowanie zaufania ponad granicami;

- współfinansowanie transnarodowych projektów, w ramach których są opracowywane, testowane i wdrażane rozwiązania pilnie potrzebne, żeby Europa Środkowa była silniejsza i atrakcyjniejsza.

Realizacji celu programu posłużą oczekiwane rezultaty projektów:

- poprawa procesu tworzenia polityk, uczenia się i wprowadzania zmian;

- podnoszenie kompetencji, w tym dzięki transferowi i wymianie wiedzy;

- bardziej skoordynowana współpraca i lepsze zarządzanie na różnych poziomach;

- zredukowanie barier;

- nowe lub lepsze usługi;

- zmiana nawyków;

- $\quad$ łączenie środków publicznych i prywatnych, w tym do przygotowania inwestycji. 
Zasięg geograficzny: Polska, Czechy, Słowacja, Austria, Węgry, Słowenia, Chorwacja, północne Włochy i część Niemiec; nowy region: Brunszwik

Priorytety:

- Priorytet 1: Współpraca na rzecz inteligentnej Europy Środkowej

- SO 1.1 - Wzmacnianie zdolności innowacyjnych

- SO 1.2 - Rozwijanie umiejętności w zakresie inteligentnej specjalizacji, transformacji przemysłowej i przedsiębiorczości

- Priorytet 2: Współpraca na rzecz bardziej zielonej Europy Środkowej

- SO 2.1 - Wspieranie transformacji energetycznej dla neutralności klimatycznej

- $\quad$ SO 2.2 - Zwiększenie odporności na zmiany klimatu

- SO 2.3 - Rozwój gospodarki o obiegu zamkniętym

- SO 2.4 - Ochrona środowiska

- SO 2.5 - Zielona mobilność miejska

- Priorytet 3: Współpraca na rzecz lepiej połączonej Europy Środkowej

- SO 3.1 - Poprawa połączeń transportowych obszarów wiejskich i peryferyjnych

- Priorytet 4: Poprawa systemu zarządzania współpracą w Europie Środkowej

- SO 4.1 - Wzmocnienie systemu zarządzania na rzecz zintegrowanego rozwoju terytorialnego w Europie Środkowej

Typy projektów (wstępne uzgodnienia; nazwy i charakterystyka projektów mogą się jeszcze zmienić):

1. z elastycznym planem działań (od 5 do 12 partnerów)

2. kapitalizacyjne (od 5 do 12 partnerów)

3. pionierskie / pilotażowe (do 12 miesięcy, partnerów od 3 do 6)

Harmonogram prac Interreg Europa Środkowa 2021-2027

- kwiecień 2021 - akceptacja projektu programu przez Grupę Roboczą

- czerwiec/lipiec 2021 - zatwierdzenie przez państwa członkowskie i złożenie do KE

- $\quad$ czerwiec 2021 - ogłoszenie warunków 1. naboru

- $\quad$ wrzesień / październik 2021 - zatwierdzenie programu przez KE

- $\quad$ wrzesień/ październik 2021 - formalne otwarcie 1. naboru projektów

\section{B. Interreg Region Morza Bałtyckiego 2021-2027}

Ogólny cel programu: „Wdrażanie innowacyjnych, polegających na inteligentnym korzystaniu z wód i neutralnych dla klimatu rozwiązań poprzez współpracę transnarodowa z korzyścią dla obywateli w całym regionie Morza Bałtyckiego".

Wspieranie transformacji: przejście do bardziej ekologicznych i odporniejszych społeczeństw i gospodarek - cyfryzacja jest głównym czynnikiem umożliwiającym tę transformację. 
Orientacja na klienta: kierowanie się potrzebami i wspieranie władz publicznych w zaspokajaniu potrzeb ich grup docelowych (np. firm i społeczności).

Transfer wiedzy i budowanie zdolności jest ważnym elementem działań ponadnarodowych w ramach wszystkich celów polityki. Poprawa kompetencji zwiększa świadomość społeczną i zmianę zachowań.

Zasięg geograficzny: Polska, Dania, Estonia, Finlandia, Łotwa, Litwa, Szwecja, część Niemiec, część Norwegii oraz część Rosji i Białoruś

\section{Priorytety:}

- Priorytet 1: Innowacyjne społeczeństwa

- $\quad$ SO 1.1 - Odporne gospodarki i społeczności

- $\quad$ SO 1.2 - Responsywne usługi publiczne

- Priorytet 2: Społeczeństwa korzystające z wody

- $\quad$ SO 2.1 - Zrównoważone wody

- $\quad$ SO 2.2 - Niebieska gospodarka

- Priorytet 3: Społeczeństwa neutralne dla klimatu

- SO 3.1 - Gospodarka o obiegu zamkniętym

- $\quad$ SO 3.2 - Transformacja energetyczna

- SO 3.3 - Inteligentna zielona mobilność

- Priorytet 4: Zarządzanie współpracą

- $\quad$ SO 4.1 - Platformy projektów

- $\quad$ SO 4.2 - Zarządzanie makroregionalne

Typy projektów (wstępne uzgodnienia; nazwy i charakterystyka projektów mogą się jeszcze zmienić):

1. regularne (duże zorientowanie na wdrażanie)

2. małe projekty (do 2 lat, przeniesienie programu bliżej obywateli)

3. platformy projektów

Harmonogram prac Interreg Region Morza Bałtyckiego 2021-2027:

- maj 2021 - akceptacja projektu programu przez komitet programujacy

- czerwiec-wrzesień 2021 - zatwierdzenie programu przez państwa członkowskie

- $\quad$ wrzesień 2021 - złożenie programu do Komisji Europejskiej

- listopad/grudzień 2021 - zatwierdzenie programu przez KE

- grudzień 2021 - planowane otwarcie 1. naboru projektów

\section{Interreg Europa 2021-2027}

Zasięg geograficzny: UE-27, Norwegia, Szwajcaria

W nowym okresie nie będzie możliwości współpracy z partnerami brytyjskimi.

Cel programu: Poprawa efektywności polityk regionalnych (wymiana doświadczeń; promocja innowacyjnych rozwiązań; budowanie zdolności instytucjonalnej). 
Jeden priorytet: Lepsze zarządzanie współpracą. Wzrost kompetencji podmiotów odpowiedzialnych za tworzenie i wdrażanie polityk regionalnych.

Uprawnieni do udziału w projektach:

- władze (krajowe, regionalne, lokalne) i instytucje publiczne

- prywatne podmioty non-profit

Dofinansowanie z Europejskiego Funduszu Rozwoju Regionalnego:

- partnerzy publiczni: $80 \%$

- partnerzy non-profit: $70 \%$

\section{Cele Polityki:}

- Cel polityki 1: Bardziej inteligentna Europa

Ulepszanie instrumentów polityki dotyczących wspierania innowacji, badań i rozwoju, szczególnie w ramach strategii inteligentnych specjalizacji. Rozwój umiejętności na potrzeby inteligentnej specjalizacji oraz przedsiębiorczości, cyfryzacja gospodarki oraz społeczeństwa, łączność cyfrowa, powszechne wykorzystanie zaawansowanych technologii, innowacje w MŚP, innowacje nietechnologiczne (organizacyjne, społeczne itp.).

- Cel polityki 2: Bardziej przyjazna dla środowiska, bezemisyjna i odporna Europa Ulepszanie instrumentów polityki dotyczących przechodzenia na gospodarkę o obiegu zamkniętym, przystosowania się do zmiany klimatu, gospodarki wodnej, zapobiegania zagrożeniom i odporności na klęski żywiołowe, efektywności energetycznej, różnorodności biologicznej i zielonej infrastruktury, zrównoważonej mobilności miejskiej.

- Cel polityki 3: Lepiej połączona Europa Ulepszanie instrumentów polityki dotyczących zrównoważonej, inteligentnej i multimodalnej mobilności.

- Cel polityki 4: Europa o silniejszym wymiarze społecznym

Ulepszanie instrumentów polityki, które pomogą ludziom w powrocie do zatrudnienia, poprawią efektywność rynków pracy oraz integrację migrantów i grup w niekorzystnej sytuacji. Zapewnienie dostępu do opieki zdrowotnej poprzez rozwój infrastruktury, w tym podstawowej opieki zdrowotnej i specjalistycznych usług zdrowotnych, zwiększenie roli kultury i turystyki w rozwoju gospodarczym, włączeniu społecznym i innowacjach społecznych.

- Cel polityki 5: Europa bliżej obywateli

Ulepszanie instrumentów polityki związanych z edukacja, włączeniem społecznym, rynkiem pracy, integracją migrantów, dziedzictwem kulturowym, turystyką.

Typy projektów:

1. Projekty współpracy międzyregionalnej

- Powiązanie z różnymi instrumentami polityki (programy, plany, strategie itp.)

- Akcje pilotażowe

- Projekty dotyczące różnych aspektów wdrażania wybranych programów, planów itp.

- Współpraca międzynarodowa i w regionie (grupy interesariuszy)

2. Platforma learningowa (Policy Learning Platform) 
- Wzajemne oceny (peer reviews)

- Pomoc ekspertów (policy help-desk)

- Webinaria

- Baza wiedzy i dobrych praktyk (knowledge hub, goood practices)

- Społeczność on line (community)

Harmonogram prac:

- Do 16 kwietnia 2021: konsultacje publiczne prowadzone na stronie programu

- Konsultacje w j. polskim prowadzone przez MFiPR do 20 kwietnia br.

- Wrzesień 2021: planowane złożenie projektu programu do Komisji Europejskiej

- Decyzja KE spodziewana w styczniu 2022 r.

- Pierwszy nabór wniosków - I połowa 2022 r.

W nowej perspektywie programowania wprowadzone zostaną zmiany, m.in. zmienią się zakresy tematyczne (większa koncentracja tematyczna), novum będą małe projekty, rozliczanie będzie uproszczone - uproszczone zostanie rozliczanie kosztów personelu i podróży. Obniżony będzie poziom dofinansowania dla podmiotów o charakterze publicznym do $80 \%$.

Na podstawie wystapień prelegentów zaprezentowanych podczas spotkania informacyjnego dotyczacego Programów Interreg Europa, Interreg Europa Środkowa, Interreg Morza Battyckiego na lata 2021-2027 opracowała Anna Kwil

Anna Kwil - absolwentka Uniwersytetu Warszawskiego, pracownik samorządowy, kontakt: Mazowieckie Biuro Planowania Regionalnegow Warszawie, ul. Nowy Zjazd 1, 00-301 Warszawa, e-mail:akwil@mbpr.pl

Anna Kwil - graduate of the University of Warsaw, regional government employee, contact: Mazovian Office for Regional Planning in Warsaw, ul. Nowy Zjazd 1, 00-301 Warszawa, e-mail:akwil@mbpr.pl 